patients with pituitary adenomas secreting prolactin. Data obtained after longer follow up are obviously required, but our early results over five years using this approach are more encouraging than those of other groups. ${ }^{61019}$

\author{
References \\ 1 Hardy J. Transsphenoidal microsurgery of the normal and pathological pituitary. Clin Neurosurg \\ 1969;16:185-217 \\ 2 Hardy J. Le prolactinome. Neurochirurgie 1981;27:1-110. \\ 3 Ludecke D, Kantzky R, Saeger $W$. Selective removal of hypersecreting pituitary adenomas; an \\ analysis of endocrine function, operative and microsurgical findings in 101 cases. Acta Neurochir \\ 1976;35:27-42 \\ 4 McLanahan CS, Christy JH, Tindall GT. Anterior pituitary function before and after \\ transsphenoidal microsurgical resection of pituitary tumours. Neurosurgery 1979;3:142-5. \\ 5 Fahlbusch R. Surgical failures in prolactinomas. In: Deroma PJ, Jedynax CP, Peillon F, eds. \\ Pituitary adenomas: biology, physiopathology and treatment. 2nd European workshop. Paris: \\ Axlepios, 1980:273-82. \\ 6 Tucker HStG, Lanaford HV, Gardner DF, Blackard WG. Persistent defect in regulation of \\ prolactin secretion following successful pituitary tumour removal in women with galactorrhoea- \\ amenorrhoea syndrome. I Clin Endocrinol Metab 1980;51:968-71. \\ 7 Llandolt AM. Surgical treatment of pituitary prolactinomas: post-operative prolactin and fertility \\ in 70 patients. Fertil Steril 1981;35:620-5. \\ 8 Randall RV, Laws ER, Abbond CF, et al. Transsphenoidal microsurgical treatment of prolactin- \\ producing pituitary adenomas. Results in 100 patients. Mayo Clin Proc 1983;58:108-21. \\ Teasdale G. Surgical management of pituitary adenoma. In: Scanlon MF, ed. Neuroendocrinology. \\ London: Saunders, 1983:789-823. (Clinics in Endocrinology and Metabolism No 12. \\ 10 Serri O, Rasio E, Beauregard H, et al. Recurrence of hyperprolactinaemia after selective \\ transsphenoidal adenomectomy in women with prolactinoma. N Englf Med 1983;309:280-7.
}

11 Thorner MO, McNeilly AS, Hagen C, Besser GM. Long term treatment of galactorrhoea and hypogonadism with bromocriptine. Br Med $\mathcal{F} 1974 ;$ ii: $419-22$.

12 Grossman A, Besser GM. Prolactinomas. Br Med J 1985;290:182-4.

13 Cowden EA, Thomson JA, Doyle D, Ratcliffe JG, MacPherson P, Teasdale GM. Tests of prolactin secretion in diagnosis of prolactinomas. Lancet 1979;i:1155-8.

14 Scanlon MF, Rodriguez-Arnao MD, Weightman D, et al. Altered dopaminergic regulation of thyrotrophin release in patients with prolactinomas: comparison with other tests of hypothalamic function. Clin Endocrinol 1981;14:133-43.

15 Massara F, Camanni F, Martra M, Dolfin GC, Muller EE, Molinatti GM. Reciprocal pattern of the TSH and PRL responses to dopamine receptor blockade in women with physiological or pathological hyperprolactinaemia. Clin Endocrinol 1983;18:103-10.

16 Chiari O. Über ein Modifikation der schlofferschen Operation von Tumoren der Hypophyse. Wien Klin Wochenschr 1912;25:5-6.

17 James A. The hypophysis. F Laryngol Otol 1967;81:1283-307.

18 Jasani B, Wynford-Thomas D, Williams ED. Use of monoclonal antihapten antibodies for immunolocalisation of tissue antigens. $\mathcal{F}$ Clin Pathol 1984;34:1000-2.

19 Charpentier G, de Plunkett T, Jedymak CP, etal. Short and long term results of surgical treatment of pituitary adenomas. In: Lamberts SWJ, Tilders SJ, Van der Veen DEE, Assies J, eds. Trends in the diagnosis and treatment of pituitary adenomas. Amsterdam: Free University Press, 1983.

20 Gordon D, Richards A, Bulloch R, et al. Prolactin dynamics and tumour size in the prediction of surgical outcome for prolactinoma. $Q$ f Med 1985;54:141-51.

21 Rodman EF, Molitch ME, Post KD, et al. Long-term follow-up of transsphenoidal selective adenomectomy for prolactinoma. IAMA 1984;252:921-4.

22 Camanni $F$, Ghigo $E$, Ciccarelli $E$, et al. Defective regulation of prolactin secretion after successful removal of prolactinomas. F Clin Endocrinol Metab 1983;57:1270-6.

23 Samaan NA, Elhaj GE, Leavens ME, Franklin RR. The clinical and biochemical features in 26 patients with prolactinoma before and after transsphenoidal microresection. Acta Endocrino 1980;94:450-8

\title{
Treatment of presumed prolactinoma by transsphenoidal operation: early and late results
}

\author{
J A THOMSON, G M TEASDALE, D GORDON, D C McCRUDEN, D L DAVIES
}

\begin{abstract}
Seventy seven patients who were presumed to have a prolactinoma on the basis of biochemical findings underwent transsphenoidal operation between October 1977 and September 1983. Sixty one patients were found to have a microadenoma, and hyperprolactinaemia was cured in 46 of these, amenorrhoea in 39 $(80 \%$ of those with the symptom), galactorrhoea in $32(80 \%)$, and infertility in 31 (82\%). Four of eight patients found to have a macroadenoma were also satisfactorily treated with surgery. Two patients had a lesion other than a prolactinoma, and in six a tumour could not be found at operation; four of these last eight patients had a normal serum prolactin concentration after operation. Recurrent hyperprolactinaemia was rare, occurring in only three patients in the series overall; among the 32 patients followed up for more than five years only two of the 22 whose operation had initially been successful developed recurrent hyperprolactinaemia.
\end{abstract}

\footnotetext{
University Departments of Medicine, Royal and Western Infirmaries, Glasgow, and Department of Neurosurgery, Southern General Hospital, Glasgow

J A THOMSON, MD, FRCP, reader in medicine

G M TEASDALE, MRCP, FRCSED, professor of neurosurgery

D GORDON, MB, MRCP, registrar in endocrinology

D C MCCRUDEN, MB, MRCP, senior registrar in endocrinology

D L DAVIES, MD, FRCP, senior lecturer

Correspondence to: Dr J A Thomson, University Department of Medicine, Royal Infirmary, Glasgow G31 2ER.
}

\section{Introduction}

An operation on the pituitary is now widely accepted as the best method of treating acromegaly and Cushing's disease, but the management of tumours producing prolactin remains controversial. Series reported from Britain have concentrated on radiotherapy and treatment with dopamine agonists such as bromocriptine; surgery has to some extent been neglected and sometimes misrepresented. ${ }^{12}$

We have treated a consecutive series of 77 patients with hyperprolactinaemia by transsphenoidal operation. We have previously reported the laboratory diagnosis of prolactinoma, ${ }^{3}$ the radiological findings,${ }^{4}$ the initial results of operation in the first 14 patients, ${ }^{5}$ the restoration of fertility and the outcome of pregnancy, ${ }^{6}$ and the factors affecting prognosis. ${ }^{7}$ This report provides an overview of the clinical and biochemical results and pays special attention to the long term outcome.

\section{Methods}

The patients included in this review each presented with amenorrhoea, galactorrhoea, or infertility. Each had a serum prolactin concentration that was persistently above normal and impaired responses to dynamic testing with thyrotrophin releasing hormone or metoclopramide. ${ }^{3}$ The serum prolactin concentration was estimated using a radioimmunoassay; the coefficient of variance of the assay was $5 \%$ within batches and $10 \%$ between batches, and our normal reference range for serum prolactin concentration was $60-360 \mathrm{mU} / \mathrm{l}^{3}$

Radiological investigation evolved during the years of the study. In each patient a plain $x$ ray film of the skull was obtained, initially coupled with tomograms of the pituitary fossa. Each patient also underwent computed tomography. Orbital phlebography was used routinely to display the venous and arterial relations of the pituitary gland. ${ }^{8}$ Carotid angiography and metrizamide cisternography and ventriculography ${ }^{9}$ were used selectively to clarify detailed anatomical abnormalities and were needed in only seven and 
eight patients, respectively. Dopamine agonists were used before operation by only 16 patients ( 11 with a microprolactinoma, four with a macroprolactinoma, and one in whom a prolactinoma was not found).

Operation was carried out by a transsphenoidal microsurgical technique. ${ }^{10}$ When a tumour was found a 1-2 mm rim of tissue at its interface with the normal gland was also removed. Preoperative histological studies were used to establish the presence of a tumour and the completeness of removal. The final diagnosis of a prolactinoma was based on the results of histologica studies, including specific immunoperoxidase staining, and of hormone assays on cell cultures.

\section{Patients studied}

Between October 1977 and September 1983, 77 women with a presumed prolactinoma underwent transsphenoidal exploration. In 69 patients a tumour was identified; of these, 61 were microprolactinomas (defined as being $\leqslant 10 \mathrm{~mm}$ in diameter) and eight were macroprolactinomas $(>10 \mathrm{~mm}$ in diameter). Two patients had another lesion, and in six patients a tumour was not found.

Within a month after operation the basal serum prolactin concentration was estimated at least twice and anterior pituitary function and reserve were tested by standard methods. ${ }^{11}$ These tests, and the response of serum
EARLY POSTOPERATIVE RESULTS

Patients with microprolactinomas $(n=61)$

Hyperprolactinaemia - Before operation the serum prolactin concentrations ranged from 560 to $11700 \mathrm{mU} / \mathrm{l}$ (mean $2952 \mathrm{mU} / \mathrm{l}$ ). One month after transsphenoidal operation 46 patients had a normal serum prolactin concentration.

Amenorrhoea-Forty nine of the patients had amenorrhoea when they presented; in 39 this was cured after surgery. Five patients had oligomenorrhoea before operation; each regained a normal cycle afterwards. In seven patients the menstrual cycle was regular before operation and remained so afterwards. Two patients had persistent postoperative amenorrhoea despite normoprolactinaemia, and in both tests with luteinising hormone releasing hormone showed a normal response of pituitary gonadotrophins to the appropriate stimulating hormone; one of the patients was grossly obese, and in both patients anovulation may have been due to hypothalamic dysfunction.

Galactorrhoea-Forty patients had galactorrhoea; in 32 this was cured by operation.

Infertility-Fifty one patients initially reported that infertility was a problem. After operation 13 of these patients changed their minds: 11 adopted various methods of contraception, one underwent hysterectomy for menorrhagia, and another became divorced. One other patient, in whom

TABLE I-Changes in serum prolactin concentrations after transsphenoidal operation in 77 patients with suspected prolactinomas

\begin{tabular}{|c|c|c|c|c|c|c|c|}
\hline \multirow[b]{3}{*}{$\begin{array}{l}\text { Findings at } \\
\text { operation }\end{array}$} & \multirow{3}{*}{$\begin{array}{c}\text { Range of } \\
\text { preoperative } \\
\text { serum prolactin } \\
(\mathrm{mU} / \mathrm{l})\end{array}$} & \multicolumn{2}{|c|}{ Early postoperative results } & \multicolumn{4}{|c|}{ Results after five years } \\
\hline & & \multirow[b]{2}{*}{$\begin{array}{c}\text { No of } \\
\text { patients }\end{array}$} & \multirow[b]{2}{*}{$\begin{array}{c}\mathrm{No}(\%) \text { with } \\
\text { prolactin }<360 \mathrm{mU} / 1\end{array}$} & \multirow[b]{2}{*}{$\begin{array}{c}\text { No of } \\
\text { patients }\end{array}$} & \multicolumn{2}{|c|}{ No with prolactin $<360 \mathrm{mU} / 1$} & \multirow{2}{*}{$\begin{array}{l}\text { No with } \\
\text { sustained } \\
\text { recurrence }\end{array}$} \\
\hline & & & & & $\begin{array}{l}\text { At initial } \\
\text { follow up }\end{array}$ & $\begin{array}{c}\text { After } \\
\text { five years }\end{array}$ & \\
\hline Microprolactinoma & $560-11700$ & 61 & $46(75 \cdot 4)$ & 28 & 21 & 19 & 2 \\
\hline Macroadenoma & $2000-83000$ & 8 & $4(50 \cdot 0)$ & 2 & 1 & 1 & \\
\hline Prolactinoma not found & $1092-3880$ & 8 & $3(37 \cdot 5)$ & 2 & 1 & 1 & \\
\hline Total & & 77 & $53(68 \cdot 8)$ & 32 & 23 & 21 & 2 \\
\hline
\end{tabular}

TABLE II-Clinical problems in eight patients with macroprolactinomas before and after transsphenoidal operation

\begin{tabular}{cccclll}
\hline \multirow{2}{*}{$\begin{array}{c}\text { Case } \\
\text { No }\end{array}$} & \multicolumn{2}{c}{ Serum prolactin $(\mathrm{mU} / \mathrm{l})$} & & & & \\
\cline { 2 - 4 } & Before operation & After operation & Amenorrhoea & Galactorrhoea & Infertility & Additional treatment \\
\hline 1 & 2000 & 400 & Cured & Cured & Cured & None \\
2 & 2064 & 96 & Cured & Cured & Cured & None \\
3 & 2280 & 300 & Cured & Cured & Not cured & None \\
4 & 4297 & 67 & Cured & NA & NA & None \\
5 & 21600 & 670 & Not cured & NA & Cured $\dagger$ & Radiotherapy, bromocriptine \\
6 & 24700 & 1600 & Not cured & Not cured & Cured $\dagger$ & Bromocriptine \\
7 & 73790 & 70000 & Not cured & Not cured & Not cured & Radiotherapy, bromocriptine, pergolide mesylate \\
8 & 83000 & 12000 & Not cured & NA & NA & Radiotherapy, bromocriptine \\
\hline
\end{tabular}

NA $=$ Not applicable.

^Patient had endometriosis; ovulation suggested by rise in progesterone concentrations.

†After treatment with bromocriptine.

prolactin concentrations to thyrotrophin releasing hormone and metoclopramide, were repeated at varying intervals in individual cases. This report is based on the data available up to the period October to December 1984. Thus the minimum possible follow up period was one year and the maximum seven years (mean 3.6 years). Forty eight patients had been followed up for three or more years and 32 for five or more years.

Three patients moved away from Glasgow and so could not be followed up long term. Two had a normal serum prolactin concentration after operation, and in one the concentration remained normal for at least one year. The third patient had a raised serum prolactin concentration of $530 \mathrm{mU} / \mathrm{l}$ after operation.

\section{Results}

TOTAL SERIES

Table I shows the overall early and late results for the 77 patients. Normal prolactin concentrations were found in 53 patients after operation and persisted in 21 of the 23 patients with normal prolactin concentrations after operation followed up for more than five years. normoprolactinaemia and apparently normal ovulatory menstruation were restored, developed a premature menopause at the age of 39 . This left 38 patients who could be considered to be attempting to become pregnant. Of these, 31 were successful, and in the remaining seven a rise of plasma progesterone concentrations $>20 \mathrm{nmol} / 1(6 \cdot 3 \mathrm{ng} / \mathrm{ml})$ was shown during the luteal phase of the menstrual cycle, providing evidence of ovulation. ${ }^{12}$

\section{Patients with macroprolactinomas $(n=8)$}

Table II summarises the information about the patients with macroprolactinomas. They separated into two groups. Four patients had a preoperative serum prolactin concentration between 2000 and $5000 \mathrm{mU} / \mathrm{l}$; in each of these the clinical problem was cured, and the serum prolactin concentration was restored to normal in three and almost to normal in one. In two of these patients the tumour was partly cystic, and this may explain the discrepancy between its size and the fairly low serum prolactin concentration. The remaining four patients had much more severe hyperprolactinaemia. Although in three the serum prolactin concentration was substantially lower after operation, in none did it reach normal. Remission of some of these patients' symptoms occurred after treatment with bromocriptine. 
Patients in whom a prolactinoma was not identified $(n=8)$

In one patient the pituitary contained tissue consistent with a diagnosis of sarcoidosis; another had a small chordoma that had eroded into the pituitary from the sphenoid bone. In both patients the serum prolactin concentration was in the normal range after operation and regular menstruation returned. Neither patient was seeking to become pregnant.

In the remaining six patients a tumour was not detected at operation and adenomatous tissue could not be found in the biopsy specimens taken. Two of these patients had a normal serum prolactin concentration after operation, recovered ovulatory menstrual function, and became pregnant. The remaining four patients still had hyperprolactinaemia; two became pregnant after treatment with bromocriptine, and two decided against attempting to conceive.

\section{COMPLICATIONS AFTER OPERATION}

Complications of the operation were usually minor bruising of the face and transient numbness of the upper lip. A brief nasal discharge was common, but in only 12 of the 69 patients with prolactinomas was this thought to be cerebrospinal rhinorrhoea. In each patient this resolved rapidly, and none required further operation. The only serious complication was a mild meningitic syndrome caused by Staphylococcus albus. The patient responded promptly to antibiotics, was cured of hypoprolactinaemia, and subsequently became pregnant.

Endocrine complications were likewise few. Transient diabetes insipidus was observed in seven patients, and 11 patients developed growth hormone deficiency. Only three patients received replacement treatment with cortisol after the immediate postoperative period, and two of these showed normal function of the hypothalamic pituitary adrenal axis when tested two and six years later; the other patient moved away from Glasgow and was not retested. Secondary hypothyroidism developed five years after operation in one patient.

\section{RECURRENT HYPERPROLACTINAEMIA}

Only three patients ( $4 \%$ of the total series) showed evidence of recurrent persisting hyperprolactinaemia. Each had a microprolactinoma, and recurrence occurred at three, 19, and 24 months after operation. These patients were discussed in a previous paper. One patient (patient 3 in table 2 of that paper) was later reviewed. She still had mild hyperprolactinaemia $(420 \mathrm{mU} / 1)$ at three years but was menstruating and apparently ovulating. She had not become pregnant, and laparoscopy showed the presence of extensive endometriosis. Each of the three patients underwent high definition computed tomography, which showed a small pituitary gland without evidence of an adenoma.

Four other patients had a transient rise in serum prolactin concentration; in three of these patients this subsequently reverted to normal without specific treatment. The fourth had late secondary hypothyroidism, and after treatment of this the hyperprolactinaemia resolved.

\section{PATIENTS FOLLOWED UP FOR LONGER THAN FIVE YEARS}

Thirty patients who had a prolactinoma ( 28 with microadenomas, two with macroadenomas) were followed up for more than five vears after operation. Ten of these patients had hyperprolactinaemia at follow up. In eight this reflected the failure of the initial operation to reduce the serum prolactin concentration to entirely normal values. Of 22 patients with an initially successful operation, only two had recurrent hyperprolactinaemia.

Twenty one of the 30 patients wished to become pregnant; 17 were successful as a result of operation, and in two further patients pregnancy occurred after treatment with bromocriptine. Thus 19 of the 21 became pregnant.

\section{Discussion}

The successful early postoperative results in this series are comparable with those in other large series of patients treated by operation. ${ }^{13 \cdot 1^{-}}$The prospect that an effective operation also leads to a permanent cure has been one of the main arguments advanced for using operation as the primary treatment for a prolactinoma. In this series recurrence of hyperprolactinaemia was indeed rare after an initially successful operation. Our findings therefore contradict the doubts about the long term efficacy of surgery recently raised by a much quoted paper from Montreal. ${ }^{1 x}$

In the present study sustained hyperprolactinaemia had returned five years after operation in only two $(9 \%)$ of 23 patients who had normal prolactin concentrations immediately after operation $(95 \%$ confidence interval $2 \%-27 \%$ ). This is in sharp contrast to the report by Serri et al of recurrence of prolactinomas in $16(55 \%)$ of 29 patients $(95 \%$ confidence interval $37 \%-73 \%) .{ }^{1 \times}$ This difference in the incidence of recurrence is significant $\left(\chi^{2}=14 ; \mathrm{df}=1 ; \mathrm{p}<0.001\right)$. Other surgical reports also quote incidences of recurrence lower than that in the Montreal review: $17 \%$ after five years ${ }^{14} ; 18 \%$ after a mean of four and a half years, ${ }^{21}$ and $24 \%$ after a mean of five and a half years (E R Laws, M J Ebersold, D G Piepgras, C F Abboud, R V Randall, B W Scheithauer. The role of surgery in the management of prolactinoma. Meeting on prolactinoma, Charlottesville, 1984)

The unrepresentatively high incidence of recurrence in the report of Serri et al may reflect several factors. ${ }^{1 \times}$ Their study was based on a selected subgroup of 44 out of a total of 105 patients who underwent operation, and all the patients with recurrent hyperprolactinaemia were treated before 1975. Since then surgical techniques have evolved and the importance of excision of the capsule of the tumour cavity and of perioperative histological studies has been recognised. ${ }^{10}{ }^{17}$ Furthermore, in four cases it was not known if the hyperprolactinaemia was sustained, because treatment with drugs had been started. None of the 16 patients had radiological evidence of regrowth of tumour, and only eight had clinical evidence of reproductive dysfunction in the form of amenorrhoea or galactorrhoea. One of the patients who had asymptomatic hyperprolactinaemia was later found to have a normal serum prolactin concentration and even became pregnant without treatment.

The finding in all series of a high rate of success in patients with a microprolactinoma highlights the need for reliable identification of such tumours. Unfortunately, none of the biochemical or radiological tests available provides a completely reliable guide. A benefit of our reliance on biochemical criteria was the finding of a microprolactinoma in many patients who had a normal pituitary fossa. The price was that six patients had an operation that did not disclose disease in the pituitary; none of them suffered ill effects, and two became fertile without further treatment.

Macroprolactinomas are easy to diagnose but commonly adhere to and infiltrate the structures surrounding the fossa; they are therefore more difficult to treat, whatever treatment is used. Nevertheless, a satisfactory result was obtained in four of our eight patients with a macroprolactinoma; indeed, cure was usual when the serum prolactin concentration was $<5000 \mathrm{mU} / \mathrm{l}$. None of the patients with a prolactin concentration $>10000 \mathrm{mU} / 1$ was cured postoperatively. In such cases transsphenoidal decompression may facilitate medical treatment and protect against enlargement of the pituitary during pregnancy. ${ }^{\circ}$

Alternative methods of treatment of prolactinomas each have their enthusiastic advocates. Dopamine agonists, especially bromocriptine, are clearly effective in suppressing hyperprolactinaemia. Although a permanent effect has been claimed, ${ }^{21}$ most regard this treatment as effective only while it is being taken. ${ }^{.2}$ Recent reports from Leeds ${ }^{23}$ and Newcastle ${ }^{24}$ reviewed 36 and 30 patients, respectively, after bromocriptine was stopped. A sustained reduction in the serum prolactin concentration occurred in only a few patients, and the concentration was maintained within the normal range in only three $(5 \%)$. The results of treating prolactinomas by intrapituitary implantation of yttrium were disappointing, and the serum prolactin concentration was restored to normal in only two of 21 patients $(10 \%) .{ }^{25}$ We have previously criticised claims about the benefits of external radiotherapy, ${ }^{2}$ which does not have a dramatic short term effect on the serum prolactin concentration. ${ }^{2 t}$ The reports of psychiatric complications after long term treatment with bromocriptine ${ }^{--}$and the occurrence of pituitary apoplexy $y^{2 \times}$ emphasise that each treatment has its side effects. The substantial risk of endocrine deficiency in patients with acromegaly treated by radiation $^{\prime \prime}$ may also be less acceptable in young women with hyperprolactinaemia.

Reports of treatment with drugs or radiotherapy often ignore the 
much greater certainty of final diagnosis in series of patients treated by operation. Fifth generation computed tomography might make it possible to establish confidently whether a patient has a microprolactinoma,${ }^{30}$ but there is mounting evidence that many radiological "abnormalities" prove at operation to be unrelated to the presence of a tumour. ${ }^{31}$ Clearly, when only biochemical and radiological information is available a prolactinoma can often be only presumed to be present. There must be considerable doubt about what exactly is being treated when non-surgical methods are used.

We conclude that it is reasonable to offer a transsphenoidal operation to a woman with hyperprolactinaemia believed to be due to a prolactinoma. Surgery is clearly preferable to irradiation in patients who are intolerant of bromocriptine or who do not wish to take drugs on a long term basis, but optimum results are obtained in patients with a small tumour and when operation is performed as the primary method of treatment. Although it is a highly specialised technique, the success of pituitary surgery for tumours producing growth hormone or adrenocorticotrophic hormone has led to the skill needed to treat prolactinomas being available in several British centres.

We acknowledge our clinical colleagues, E H McLaren, S Slater, J E Thomson, and $\mathrm{C}$ Thomson, who managed some of these patients and provided data for this report. We also thank Dr G Beastall (clinical biochemistry) for the hormone assays and our colleagues in neuroradiology and neuropathology for their parts in the diagnosis and management of these patients.

\section{References}

1 Grossman A, Cohen BL, Charlesworth M, et al. Treatment of prolactinomas with megavoltage radiotherapy. Br.Med f 1984;288: 1105-9.

2 Teasdale G, Thomson JA, Macpherson P. Treatment of prolactinomas with megavoltage radiotherapy. Br.Med f 1984:288:1538-9.

3 Cowden EA, Ratcliffe WA, Beastall GH, Ratcliffe JG. Laboratory assessment of prolactin status. Ann Clin Biochem 1979;16:113-21

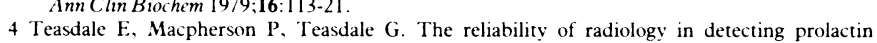
Teasdale E, Macpherson P, Teasdale G. The reliability of radi
secreting pituitary microadenomas. Br $\mathcal{F}$ Radiol $1981 ; 54: 568-71$.

5 Cowden EA, Ratcliffe JG, Thomson JA, Macpherson P, Doyle D, Teasdale G. Tests of prolactin secretion in diagnosis of prolactinomas. Lancet 1979;i:1155-8.

6 Richards A, Bullock R, Teasdale G, Thomson JA. Fertility and pregnancy after operation for a prolactinoma. Brf Obstet Gynaecol (in press)
7 Gordon D, Richards A, Bullock R, et al. Prolactin dynamics and tumour size in the prediction of surgical outcome for prolactinoma. Q f 11ed 1985:54:141-51.

8 Teasdale G, Macpherson P. Use of cavernous sinography to detect aneurysm or anomalies of the infraclinoid carotid artery. 7 Neurosurg 1982;57:637-41.

9 Macpherson P. Combined metrizamide ventriculogram and cisternogram via sub occipital route. Brf Radiol 1980;53:733-4.

10 Teasdale G. Surgical management of pituitary adenoma. Clin Endocrinol Metab 1983;12:789-824.

11 Harsoulis P, Marshall JC, Kukus SF, Burke CW', London DR, Fraser TR. Combined test for assessment of anterior pituitary function. Br.Med f 1973;iv:326-9.

12 Wathen NC, Perry L, Lilford PJ, Chard T. Interpretation of single progesterone measurement in diagnosis of anovulation and defective luteal phase: observations on analysis of the normal diagnosis of anovulation and

13 Randall RV, Laws ER, Abboud CF, Ebersold MJ, Kao PC, Scheithauer BW. Transsphenoidal microsurgical treatment of prolactin producing pituitary adenoma. Mayo Clin Proc 1983;58 $108-21$

14 Marcovitz S, Hardy J. Combined medical and surgical treatment of prolactin pituitary tumours Seminars in Reproductive Endocrinology 1984;2:73-81

15 Tucker H, Grubb SR, W'igand JP, et al. Galactorrhoea-amenorrhoea svndrome: follow up of forty-five patients after pituitary tumour removal. Ann Intern Med 1981;94:302-7.

16 Faria MA, Tindall GT. Transsphenoidal microsurgery for prolactin secreting pituitary adenomas. Results in 100 women with amenorrhoea-galactorrhoea syndrome. 7 Neurosurg 1982:56:33-43.

7 Hardy J 1981. Le prolactinomie. Neurochirurgie 1981;27 suppl 1):1-110.

18 Serri O, Rasio E, Beauregard H, Hardy J, Somma M. Recurrence of hyperprolactinaemia after selective transsphenoidal adenomectomy in women with prolactinoma. $N$ Engl $f$ Med 1983;309:280-2

19 Charpentier G, de Plunkett T, Jednnak CP, Peillon F, Derome P. Surgical treatment of prolactinomas. Short and long term results: prognostic factors. Horm Res (in press).

20 Biller BJ, Reichcin S, Rodman EF, Molitch ME. Post MD 1984 long term follow-up to transsphenoidal adenomectomy for prolactinoma. FAMA 1984;252:921-4

21 Jacobs HS. Abnormal prolactin secretion in men and women. In: Grosignami PG, Rubin BL, eds. Endocrinology of human infertility. New aspects. London: Academic Press, 1981:129-38.

22 Bergh T, Millis SJ, Wide L. Menstrual function and serum prolactin levels after long-term bromocriptine treatment of hyperprolactinaemic amenorrhoea. Clin Endocrinol 1982;16 $587-93$

23 Hancock KW, Scott JS, Lamb JT, Gibson RM, Chapman C. Long term suppression of prolactin concentrations after bromocriptine induced regression of pituitary tumours. $\mathrm{Br}$. Med 1985;290:117-8.

24 Johnstone DG, Prescott RWG, Kendall-Taylor P, et al. Hyperprolactinaemia: long term effects of bromocriptine. Am f Med 1983;75:868-79.

25 Kelly W'F, Mashiter K, Doyle FH, Banks LM, Joplin GF. Treatment of prolactin-secreting pituitary tumours in young women by needle implantation of radioactive yttrium. $Q \mathcal{F}$ Med 1978;47:473-93.

26 Nabarro JDN. Pituitary prolactinomas. Clin Endocrinol 1982;17:129-55.

27 Turner TH, Cookson JC, Wass JAH, Drury PL, Price PA, Besser GM. Psychotic reactions during treatment of pituitary tumours with dopamine agonists. Br Med f 1984;289:1101-3.

28 Wakai S. Fukushima T. Teramoto A, Sano K. Pituitary apoplexy; its incidence and clinical significance. I Neurosurg 1981;55:187-93.

29 Eastman RC. Gordon P. Roth J. Conventional supervoltage irradiation is an effective treatment for acromegaly. 7 Clin Endocrnol Metab 1979;48:931-40.

30 Jung RT, White MC, Bowles NB, Bydder G, Mashiter K, Joplin GF. CT abnormalities of the pituitary in hyperprolactinaemic women with normal or equivocal sellae radiologically. $\mathrm{Br}$ Med f 1982;285: 1078-81.

31 Davis PC, Hoffman JC, Tindall GT, Braun IF. Prolactin secreting pituitary microadenomas: inaccuracy of high resolution CT scanning. A7NR 1984;5:721-6.

Accepted 29 fulv 1985

\section{MATERIA NON MEDICA}

\section{Footprints of crime}

Exactly 300 years ago, in 1685, two brothers quarrelled over a "worthless woman" and fought a duel in Southampton Fields. The spot has since become familiar to visitors to BMA House under the name of Tavistock Square. In their frenzy the brothers trampled the grass until one of them fell mortally wounded in an agonised posture on the ground. The woman meanwhile watched them from a nearby bank. According to legend the depression made in the ground by the dead brother's body and their footmarks in the turf were visible as bare hollows a century later. A letter dated 1778 and published in the Gentleman's Magazine in 1804 recounts the story and tells how the traces remained on the ground despite attempts to obliterate them by ploughing. The writer of that letter had visited the spot and there saw, in addition to the duellists' traces, a hollow where the woman was supposed to have sat watching them

This account of the legend comes from a delightful book by Jennifer Westwood, recently published, Albion: a guide to legendary Britain (Granada, $£ 12.95)$. As befits an author who is a graduate of both Oxford and Cambridge her text is scholarly and precise, and she includes interesting comparative data. She notes for instance that the underlying theme of this legend was at one time commonly believed, namely the imprinting of the ground by the footsteps or bodies of people who had committed a crime there. Nor need the legend die yet. For she describes how she too visited the spot where the duel was fought-now the southwest corner of the lawn in Tavistock Square -and tells us: "I am happy to report that there are bare patches there which could be taken for footprints." The curiosity to see these patches was also too much for me, so on a visit to BMA House a few weeks ago I visited the fatal ground. And I am delighted to say the patches are still there, irregular depressions partly bare of grass, where the brothers fought and one of them died under the gaze of the "worthless woman."-T D v swinscow, Devon.

\section{Straightening up for the cup}

I was always slightly bandy, but a rugger accident in my student days, and the subsequent arthritis which developed, produced a remarkable increase in the bowing. When both my feet were touching each other you could almost kick a football between my knees. Friends could recognise me half a mile away by my legs, and some would inquire when I had been a jockey. Recently a knee replacement has produced a leg as straight as a ballet dancer's, but when walking I have a mild list to port and my wife hardly recognises me a hundred yards away.

The benefits of a knee replacement are not immediately apparent. Unlike after a hip operation recovery of full function takes several months and the patient must dedicate himself to a routine of ice packs, physiotherapy, and a good deal of patience. My surgeon tells me I shall probably be able to play golf next spring, but in the meanwhile I can practise chipping and putting. (A proficiency in these departments of the game is especially valuable to elderly golfers who cannot compete with the long shots launched by younger men.)

Hip replacement patients have an exclusive golfing society and converge on the Royal Berkshire or some comparable course for an annual meeting, all wearing a special tie and zealous to win the competition. Knee replacements are at present relatively few compared with the assembly line flow of hip prostheses. For this reason I propose to suggest that at this stage a wealthy member of my club should present a cup for members who have had a knee replacement: the match to be played over five holes, preferably from the ladies' tee, and on ground as level as a cricket pitch. By the springtime I shall be, I hope, a deadly chipper and putter, and as at present I am the only player eligible to enter this competition there is a strong probability that I shall win the trophy. I have waited a long time to see a silver cup gleaming on my sideboard.-PETER BEATTIE, Norwich. 